\title{
MORPHOLOGICAL DIVERSITY OF POLLEN FROM SELECTED SPECIES OF THE GENUS TARAXACUM, ACCORDING TO THEIR PLOIDAL LEVEL
}

\author{
Jolanta Marciniuk ${ }^{1}$, Anna Rudzińska-Langwald ${ }^{2}$ \\ ${ }^{1}$ Department of Botany, University of Podlasie, Prusa 12, 08-110 Siedlce, Poland \\ e-mail: jolam@ap.siedlce.pl \\ ${ }^{2}$ Department of Botany, Warsaw University of Life Sciences (SGGW), Nowoursynowska 159, 02-776 Warszawa, Poland \\ e-mail: anna_rudzinska_langwald@sggw.pl
}

Received: 14.09.2007

S u m m a r y

The study of the morphology of pollen concerned eight species of the genus Taraxacum. Seven types were chosen with a different number of chromosomes belonging to the section Palustria: Taraxacum paucilobum $2 \mathrm{n}=3 \mathrm{x}=24$, T. subdolum $2 \mathrm{n}=$ $3 \mathrm{x}=24$, T. subpolonicum $2 \mathrm{n}=3 \mathrm{x}=24$, T. vindobonense $2 \mathrm{n}=4 \mathrm{x}$ $=32$, T. trilobifolium $2 \mathrm{n}=4 \mathrm{x}=32$, T. mendax $2 \mathrm{n}=5 \mathrm{x}=40, \mathrm{~T}$. portentosum $2 \mathrm{n}=$ ? and one type from the section Obliqua $-\mathrm{T}$. platyglossum $2 n=$ ?. Pollen from all the examined species was observed by SEM microscopy.

A distinct relation exists between the morphology of pollen and the way of reproduction. Pollen of triploidal species, being compulsory apomicts, is characterized by a great variability of the size and a high percentage of deformed pollen grains. Tetraploids, being optional apomicts, produce regular pollen with a relatively even size.

The regular type of pollen in pentaploidal Taraxacum mendax and in species with an unknown number of chromosomes (Taraxacum portentosum and T. platyglossum) suggests that these taxa are optional apomicts.

Key words: Taraxacum, pollen morphology, SEM microscopy

\section{INTRODUCTION}

The genus Taraxacum Wigg. involves one of the biggest apomictic complexes of Magnoliophytina, at present there are nearly 3000 recognised species, divided into 51 sections (K i r s chner and Š tě páne k, 1997, 2004; U h le m a n n et al. 2004).

Today there are about 400 species present in Poland, in 13 sections, 300 of which have been assigned to the section Ruderalia (Gło w a c k i, 2004; M i r e k et al. 2002; Trá vníč e k et al. 2007). This large and diverse group, in terms of morphological, caryological, biochemical and ecological criteria, is well known under a historical (nom. conservantum), but inappropria- te name of Taraxacum officinale. This name at present refers to the nomenclatoric boreal type of the middle section of Taraxacum which does not exist in Europe (Kirs chner and Št ěpánek, 1997). Blossoming dandelions of the section Ruderalia are considered to be important apicultural, nutritional and healing plants (Podbielkowski, 1992; Podbielkowski and Sudnik-Wójcikowska, 2003). The research conducted so far, concerning pollen efficiency and honey yield of dandelion flowers, has been related to general species of Taraxacum officinale (W a r a k o m s k a, 1972; Demianowicz, 1979; Warakom ska, 2002; Weryszko-Ch mie lewska and Chwil, 2006), while there are numerous and well known species (including Ruderalia) that do not produce pollen or just a little amount of pollen. It must result in their variable efficiency and honey yield, depending on the species. Differences in the size, shape and amount of produced pollen result from the ploidal number and related ways of reproduction (D o 11, 1973; S t e r k et al. 1982). Diploidal species of $2 n=16$ use sexual reproduction and they produce significant amounts of regular pollen with little size diversity. Triploidal plants with $2 \mathrm{n}$ $=24$ reproduce in an apomictic way and obligatory apomixion is quite typical for them. Species that reproduce in this way produce pollen of diverse size, with numerous traits that suggest degeneration. K o śc ińs k a $\mathrm{P}$ a j ą k (2006) observed two- and three-nuclear pollens in triploidal Taraxacum alatum, quite often they were narrowed and deformed. Species from higher ploidal number levels behave in a variable way. Tetraploids are quite often facultative apomictics that are capable of occasional sexual reproduction. Their pollen is regular and of low diversity scale (M a ł e c k a, 1965; 1967; 1973). In other poliploidal complexes (e.g. Achillea gender), a significant corelation has been proven between the size of pollen and the ploidal level (D ą b r o w s k a, 1971). 
In this paper, an analysis of the morphology and size of pollen from selected dandelion species from the sections Palustria and Obliqua is presented. A close relation of these taxa to their natural and semi-natural location excludes the influence of industrial contamination.

\section{MATERIALS AND METHODS}

The research was conducted in 2006. Pollen of eight dandelion species was observed in the scanning microscope, seven of them belonging to the section $\mathrm{Pa}$ lustria (Taraxacum paucilobum, T. portentosum, T. vindobonense, T. trilobifolium, T. mendax, T. subpolonicum, T. subdolum) and Taraxacum platyglossum from the boreal, not present in Poland, section Obliqua.

Pollen for the analysis was taken from 14 herbarium specimens. For each of the species, a few hundreds pollen grains from at least three flower buds were observed. The sporoderm area was observed by scanning electronic microscopy. The open thecae were glued onto the microscopic table and sprayed with gold. SEM examination was carried out at the Nencki Institute of Experimental Biology in Warsaw.

Precise data, concerning their taxonomy appurtenance, origin and place of the material deposit, have been presented in Tab. 1 .

\section{RESULTS}

Morphological diversity of pollen from different species seems to correlate with the chromosome number of the plants. Triploidal species - Taraxacum paucilobum, T. subpolonicum and T. subdolum (Figs $1 \mathrm{a}, \mathrm{d}, \mathrm{e})$ - have pollen of variable size and shape of grains, along with giant grains there are some dwarfish pollen grains. On the surface of the pollen numerous deformations were present, with a different shape and number of cavities (lacunae) as well as asymmetrical ribs.

The homogenic size and shape of pollen grains were typical for tetraploidal species $-T$. vindobonense and T. trilobifolium (Figs $1 \mathrm{c}, \mathrm{g}$ ); a similar regular and even size of pollen grains was observed in pentaploidal Taraxacum mendax (Fig. 1 f). Pollen from $\mathrm{Ta}$ raxacum portentosum (the species with an unknown chromosome number) possessed pollen of an even size, but most pollen grains were deformed - they were either asymmetrical or had a variable number and shape of lacunae and an irregular pattern of ribs (Fig. 1 b). Pollen from Taraxacum platyglossum had grains of similar size and regular shape. Small and difficult to notice lacunae were specific in this species (Fig. 1 h).

Table 1

Location of researched dandelions` populations.

\begin{tabular}{|l|l|l|l|}
\hline \multicolumn{1}{|c|}{ Species } & \multicolumn{1}{|c|}{ Location } & \multicolumn{1}{c|}{ Collected by } & \multicolumn{1}{c|}{ Designation } \\
\hline Taraxacum paucilobum & $\begin{array}{l}\text { Kudelicze } \\
\text { Kamienna Wólka }\end{array}$ & $\begin{array}{l}\text { Z. Głowacki } \\
\text { Z. Głowacki }\end{array}$ & $\begin{array}{l}\text { Z. Głowacki } \\
\text { J. Kirschner et J. Štěpánek }\end{array}$ \\
\hline Taraxacum portentosum & Stasin (Czubaki) & Z. Głowacki & J. Štěpánek \\
\hline Taraxacum vindobonense & Czarnystok & J., P. Marciniuk & J. Štěpánek \\
\hline Taraxacum subpolonicum & Wilczonek & Z. Głowacki & J. Kirschner et J. Štěpánek \\
\hline Taraxacum mendax & $\begin{array}{l}\text { Czech Republic } \\
\text { Tarnów Jezierny }\end{array}$ & $\begin{array}{l}\text { J. Štěpánek } \\
\text { E. Kozioł }\end{array}$ & $\begin{array}{l}\text { J. Štěpánek } \\
\text { J. Kirschner }\end{array}$ \\
\hline Taraxacum trilobifolium & Polanowo & Z. Głowacki & Z. Głowacki \\
\hline Taraxacum subdolum & Pionki & Z. Głowacki & J. Kirschner et J. Štěpánek \\
\hline Taraxacum platyglossum & Groenstrand (Danmark) & Z. Głowacki & H. Øllgaard \\
\hline
\end{tabular}




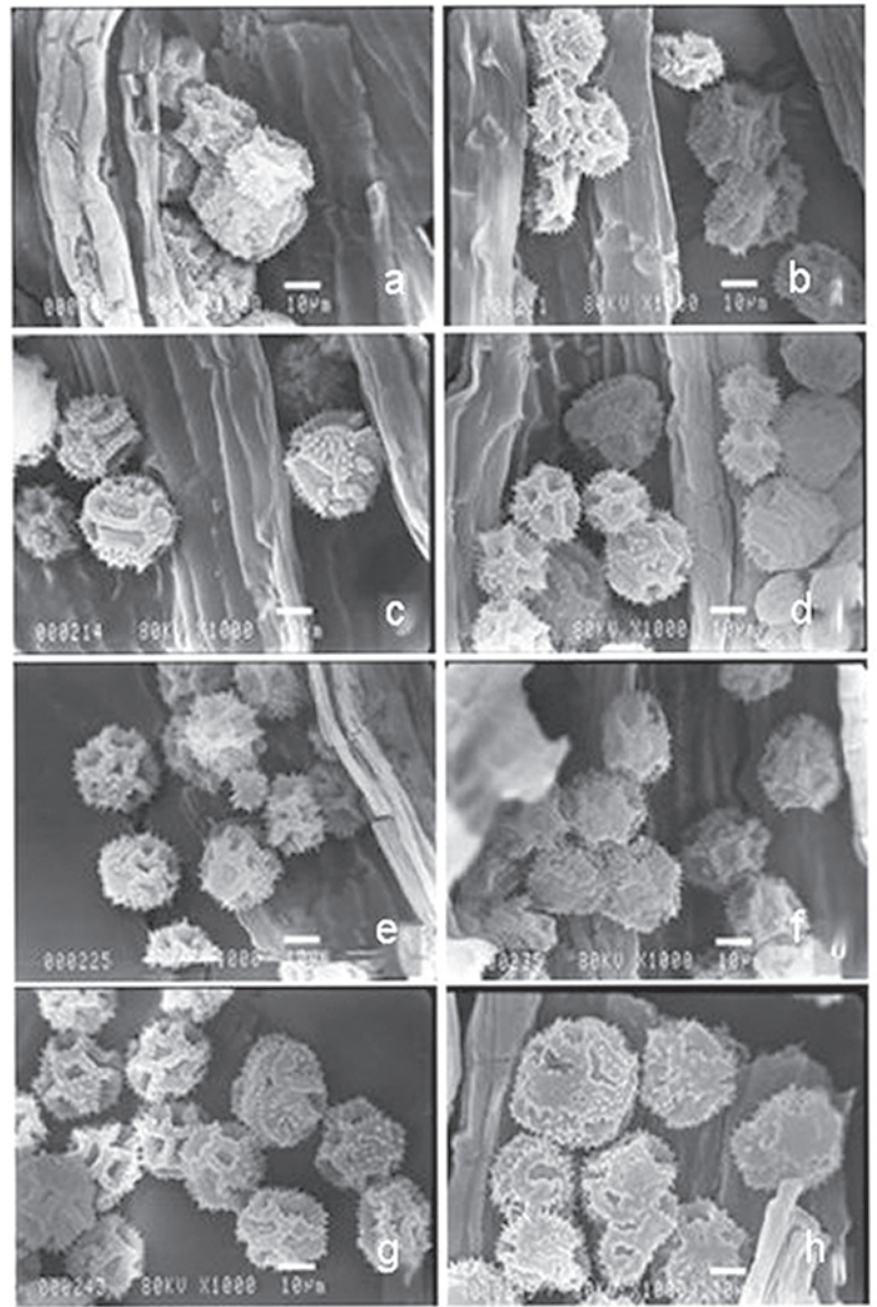

Fig. 1. Morfological diversity of pollen from selected species of Taraxacum.

a. Taraxacum paucilobum; b. Taraxacum portentosum; c. Taraxacum vindobonense; d. Taraxacum subdolum;

e. Taraxacum subpolonicum; f. Taraxacum mendax; g. Taraxacum trilobifolium; h. Taraxacum platyglossum.

\section{DISCUSSION}

The poliploidal number in dandelions resulted from spontaneous hybridisation between different species, typical for the natural world. Coming into existence in the end, poliploidal bastardized types as a rule demonstrate smaller or greater disorders of the process of meiosis and they use the apomictic way of reproduction (K i r s c h n e r and Š tě p á n e k, 1996). Morphological diversity of pollen in Taraxacum, according to S te r k et al. (1982), must be combined above all with the way of reproduction. The authors showed that sexual diploids produced very regular pollen of almost balanced size; species with optional or partly sexual apomicts produce regular pollen of little scale of diversity.

Compulsory apomicts produce irregular pollen with a very changeable size or do not produce it at all. The pollen of the examined types belongs to two catego- ries suggested by $\mathrm{S}$ te r k et al. (1982). Triploidal species - Taraxacum paucilobum, T. subdolum and T. subpolonicum - produce irregular pollen of variable size that proves disordered meiotic transitions which result in the creation of grains with a changeable number of chromosomes, from haploidal to unreduced triploidal grains (Martonfiova, 2006). The production of deformed and multinuclear grains is typical for such transitions and quite frequent (M a ł e c k a, 1964; K o ś c iń s k a $\mathrm{P}$ a j ą $\mathrm{k}$, 2006). Relatively regular pollen of even size was reported in tetraploidal Taraxacum vindobonense and T. trilobifolium, pentaploidal T. mendax as well as in $T$. portentosum (an unknown number of chromosomes). Regular and even pollen proves normal processes of meiosis and they are typical of optional apomicts (Sterk et al. 1982). The correct course of meiosis, producing regular pollen, and the occasional ability of sexual reproduction in tetraploidal Taraxacum 
vindobonense and pentaploidal Taraxacum skalinskanum have been indicated by M a ł e k a (1973). Observed in SEM, pollen of Taraxacum platyglossum (the number of chromosomes unknown to the authors) had a big and even size and a regular shape of the grain. Such a structure of pollen proves the correct course of microsporogenesis, which is very interesting in the species that frequently does not produce pollen ( $\mathrm{D} \mathrm{u} \mathrm{d} \mathrm{m} \mathrm{a} \mathrm{n}$ and $\mathrm{Richards}, 1997)$. It is possible that it results from caryological diversity of Taraxacum platyglossum. This issue needs more detailed research.

\section{CONCLUSIONS}

1. Pollen from apomictic Taraxacum gender possesses a large variety of size and shape.

2. The variation mentioned above is correlated with the way of reproduction and, to a large extent, with the ploidal number level.

3. Tetraploidal species, being facultative apomicts, produce regular pollen with little scale of variation. On the other hand, triploid species produce irregular pollen with large scale of variation and a high percentage of deformed pollen grains.

\section{ACKNOWLEDGEMENTS}

The authors would like to thank the anonymous reviewer for valuable remarks and suggestions concerning the paper.

\section{REFERENCES}

Demianowicz Z. 1979. Nektarowanie i wydajność miodowa Taraxacum officinale Web. / Nectar secretion and honey yield of Taraxacum officinale Web. Pszczel. Zesz. Nauk. 23: 97-103.

Dąbrowska J. 1971. Wielkość komórek szparkowych i pyłku u czterech gatunków Achillea L. / The size of stomata guard cells and of pollen grains in four Achillea L. species. Herba Pol. 17: 13-30.

Doll R. 1973. Revision der sect. Erythrosperma Dahlst. emend. Lindb. f. der Gattung Taraxacum Zinn. Feddes Repertorium, 83(9-10): 673-740.

Dudman A. A., Richards A. J. 1997. Dandelions of Great Britain and Ireland. Botanical Society of the British Isles, London 9.

Głowacki Z. 2004. Morfologia i taksonomia rodzaju Taraxacum (Asteraceae). / Morphology and taxonomy of the genus Taraxacum (Asteraceae). Fragm. Flor. Geobot. Polonica Suppl. 6: 59-64.

Kirschner J., Štěpánek J. 1996. Modes of speciation and evolution of the sections in Taraxacum. Folia Geobot. Phytotax. 31: 415-426.

Kirschner J., Štěpánek J. 1997. A nomenclatural checklist of supraspecific names in Taraxacum. Taxon, 46: 87-98.
Kirschner J., Štěpánek J. 2004. New sections in Taraxacum. Folia Geobot. 39: 259-274.

Kościńska-Pająk M. 2006. Biologia rozmnażania apomiktycznych gatunków Chondrilla juncea L., Chondrilla brevirostris L. i Taraxacum alatum Lindb. $\mathrm{z}$ uwzględnieniem badań ultrastrukturalnych i immunocytochemicznych. / Biology of reproduction of apomictic species Chondrilla juncea L., Chondrilla brevirostris L. and Taraxacum alatum Lindb. including ultrastructural and immunocytochemical studies. Krakowska Oficyna Naukowa TEKST, pp.104.

Małecka J. 1964. Multinucleate pollen grains in Taraxacum serotinum. Acta Biol. Cracov. Ser. Bot. 7: 107-116.

Małecka J. 1965. Embryological studies in Taraxacum palustre. Acta Biol. Cracov. Ser. Bot. 8: 224-235.

Małecka J. 1967. Processes of intraspecific differentiation in the genus Taraxacum. Genetica Polonica, 8: 185-188.

Małecka J. 1973. Problems of the mode of reproduction in microspecies of Taraxacum section Palustria Dahlstedt. Acta Biol. Cracov. Ser. Bot. 16: 38-84.

Martonfiova L. 2006. Possible pathways of the gene flow in Taraxacum sect. Ruderalia. Folia Geobot. 41: 183-201.

Mirek Z., Piękoś-Mirkowa H., Zając A., Zając M. 2002. Flowering plants and pteridophytes of Poland. A checklist. Biodiversity of Poland (ed. Z. Mirek) 1. W. Szafer Institute of Botany, Polish Academy of Sciences, Kraków.

Podbielkowski Z. 1992. Rośliny użytkowe. Wyd. Szkolne i Pedagogiczne, Warszawa.

Podbielkowski Z., Sudnik-Wójcikowska B. 2003. Słownik roślin użytkowych. PWRiL, Warszawa.

Sterk A. A., Den Nijs J. C. M., Kreune K. 1982. Sexual and Agamospermous Taraxacum Species in the Netherlands. Acta Bot. Neerl. 31 (3): 227-237.

Trávníček B., Marciniuk J., Žíla V. 2007. New localities of Taraxacum species from $\mathrm{S}$ Poland (with nine new species for Polish flora). Acta Soc. Bot. Pol. 76 (3): 209-224.

Uhlemann I., Kirschner J., Štěpánek J. 2004. The genus Taraxacum (Asteraceae) in the Southern Hemisphere. I. The section Antarctica Handel-Mazzetti and notes on dandelions of Australasia. Folia Geobot. 39: 205-220

Warakomska Z. 1972. Badania nad wydajnością pyłkową roślin. / Studies on pollen yield of plants. Pszczel. Zesz. Nauk. 16: 63-87.

Warakomska Z. 2002. Miód i pyłek z mniszka (Taraxacum Zinn em. Web.). / Honey and Pollen of Dandelion ( $\mathrm{Ta}$ raxacum Zinn em. Web.). Ann. UMCS, sect. EEE, 10: 107-112.

Weryszko-Chmielewska E., Chwil M. 2006. Morfologia prezentera pyłkowego i polimorfizm ziaren pyłku Taraxacum officinale F. H. Wigg. / The morphology of pollen presenter and polymorphism of pollen grains Taraxacum officinale F. H. Wigg. Acta Agrobot. 59 (2): 109-120. 


\section{Zróżnicowanie morfologiczne pyłku wybranych gatunków rodzaju Taraxacum w zależności od poziomu ploidalności}

\section{Streszczenie}

Studia nad morfologią pyłku przeprowadzono dla ośmiu gatunków rodzaju Taraxacum. Wybrano siedem gatunków o zróżnicowanej liczbie chromosomów należących do sekcji Palustria: Taraxacum paucilobum $2 \mathrm{n}$ $=3 \mathrm{x}=24$, T. subdolum $2 \mathrm{n}=3 \mathrm{x}=24$, T. subpolonicum $2 \mathrm{n}$ $=3 \mathrm{x}=24, T$. vindobonense $2 \mathrm{n}=4 \mathrm{x}=32$, T. trilobifolium $2 \mathrm{n}=4 \mathrm{x}=32, T$. mendax $2 \mathrm{n}=5 \mathrm{x}=40, T$. portentosum $2 \mathrm{n}$ $=$ ? oraz jeden gatunek z sekcji Obliqua - T. platyglossum $2 \mathrm{n}=$ ?. Pyłek wszystkich gatunków obserwowano w skaningowym mikroskopie elektronowym SEM.
Istnieje wyraźna zależność pomiędzy morfologią pyłku a sposobem rozmnażania. Pyłek gatunków triploidalnych, będących obligatoryjnymi apomiktami charakteryzuje się dużą zmiennością wielkości oraz wysokim odsetkiem ziaren zdeformowanych. Tetraploidy będące apomiktami fakultatywnymi wytwarzają pyłek regularny, o stosunkowo wyrównanej wielkości. Regularny typ pyłku u pentaploidalnego Taraxacum mendax oraz u gatunków o nieznanej liczbie chromosomów (Taraxacum portentosum i $T$. platyglossum) pozwala przypuszczać, że taksony te są apomiktami fakultatywnymi. 
